Article

\title{
Nature-Based Designs to Mitigate Urban Heat: The Efficacy of Green Infrastructure Treatments in Portland, Oregon
}

\author{
Yasuyo Makido ${ }^{1}$, Dana Hellman ${ }^{2} \mathbb{D}$ and Vivek Shandas ${ }^{1, *}$ \\ 1 School of Urban Studies \& Planning, Portland State University, Portland, OR 97201, USA; ymakido@pdx.edu \\ 2 School of the Environment, Portland State University, Portland, OR 97201, USA; dhellman@pdx.edu \\ * Correspondence: vshandas@pdx.edu; Tel.: +1-503-725-5222
}

Received: 30 March 2019; Accepted: 17 May 2019; Published: 21 May 2019

\begin{abstract}
Urban heat is a growing environmental concern in cities around the world. The urban heat island effect, combined with warming effects of climate change, is likely to cause an increase in the frequency and intensity of extreme heat events. Alterations to the physical, built environment are a viable option for mitigating urban heat, yet few studies provide systematic guidance to practitioners for adapting diverse land uses. In this study, we examine the use of green infrastructure treatments to evaluate changes in ambient temperatures across diverse land uses in the city of Portland, Oregon. We apply ENVI-met ${ }^{\circledR}$ microclimate modeling at the city-block scale specifically to determine what built environment characteristics are most associated with high temperatures, and the extent to which different physical designs reduce ambient temperature. The analysis included six green infrastructure interventions modeled across six different land-use types, and indicated the varying degrees to which approaches are effective. Results were inconsistent across landscapes, and showed that one mitigation solution alone would not significantly reduce extreme heat. These results can be used to develop targeted, climate- and landscape-specific cooling interventions for different land uses, which can help to inform and refine current guidance to achieve urban climate adaptation goals.
\end{abstract}

Keywords: urban heat; resilience; built environment; green infrastructure; nature-based solutions

\section{Introduction}

Across the planet, both natural and modified ecosystems are in the grip of climate change, subject to dramatic shifts in weather patterns, resource availability, and global temperature. Among the many pressing concerns related to climate change is a surge in powerful, long-lasting heat waves, a phenomenon that is projected to intensify in the future [1,2]. While some areas experience more intense heat than others, this is a widespread issue; for example, cities all across the United States are projected to see an increase in the number of extremely hot days over this century [3]. Extreme heat events of the past few decades have created major disturbances including infrastructure damage, economic loss, and human illness and death [4-8], the latter two of which have been shown to disproportionately impact vulnerable populations, such as the elderly, low-income, and those with pre-existing health conditions [9-12]. Considering the current and expected future influence of extreme heat on public health, social welfare and urban resilience, local decision makers have a duty to identify and mitigate sources of excess heat within their cities.

Urban areas are uniquely susceptible to extreme heat events, owing to a phenomenon known as the urban heat island effect (UHI) [13]. Emerging studies in the physical sciences help to explain the relationship between UHI and urban thermodynamics [14-17], and these provide a foundation for understanding how changes in the physical environment affect microclimates. Cityscapes are 
dominated by grey infrastructure: hard, impervious surfaces such as roads and buildings which trap heat; many feature relatively little green or blue infrastructure such as waterways, trees and other vegetation, which offer cooling via shade or evapotranspiration [18-20]. Occasionally, tall buildings can be protective, for example, by shading streets in the central business district during the afternoon [21]. However, grey elements of the built environment trap heat and contribute considerably to rising temperatures in the city. The UHI phenomenon and its relationship with rising temperatures is increasingly relevant across the planet, as $54 \%$ of the global population currently lives in urban areas [22].

A growing body of literature emphasizes the role of built environment alteration as a strategy for heat mitigation [23-27]. This is based largely upon previous studies which show intra-urban variation in $\mathrm{UHI}$ intensity, and indicate that differences in the built environment amount to temperature variation [21,28,29]. Commonly proposed interventions include tree planting, use of green roofs and an overall increase in green spaces [30-32], as well as lightening roads, roofs, and buildings to increase albedo [33,34], all of which have been shown effective in combating extreme heat. While such studies are helpful in guiding initial heat mitigation efforts, they are quite general and face several challenges which make them not wholly useful in practice. For example, areas vary in the composition and configuration of landscape features, and recommending greening in an industrial area that contains little planting spaces may prove moot. Similarly, effectiveness of a particular cooling strategy is sometimes given as an average value, not specific to a unique city, location, or climate [26]. Those case studies that do refer to a specific location typically do not offer models that can be simply reproduced in other locations [24]. Studies of heat mitigation in the built environment often refer to urban areas as homogeneous units, with limited differentiation between intra-urban land cover types [25], making the application of mitigation techniques difficult or ineffective at best. We attempt to address these shortcomings and to guide effective urban heat mitigation efforts by using a model that (1) is adaptable to distinct cities and land uses, providing thresholds of mitigation potential; and (2) describes various land-cover types within the city and thus indicates a range of best intervention strategies, rather than one generalized approach.

This study aims to provide local governments and planners with accurate, practicable information which may inform best practices for urban heat mitigation and adaptation. Our analysis identifies those land-use and land-cover types that contribute most to the formation of urban heat islands, as well as interventions that can best ameliorate extreme heat stress. We address the following questions: (1) what built environment characteristics are associated with high temperatures at the scale of a city-block? and (2) to what extent are alternative physical designs expected to reduce ambient temperatures in UHI? We address these questions through a thorough assessment of Portland, Oregon using a complex fluid dynamics model called ENVI-met ${ }^{\circledR}$; this microclimate modeling system simulates the temperature effects of alternative buildings scenarios. Ali Toudert's [35] review of numerical models at the micro-scale with fine temporal resolutions concludes that ENVI-met is currently the only micro-scale computational fluid dynamic model that is capable of analyzing the thermal comfort regime at fine resolutions. Additionally, Skelhorn [36] reviewed a number of models and selected ENVI-met for its capability for modeling surface-plant-air interactions in the urban environment. Other advantages of applying ENVI-Met are the high level of detail in handling multilayer vegetation, and its inclusion of latent heat and soil moisture.

Our study considers a promising field of research which aims to address urban climate adaptation to extreme heat: nature-based solutions (NBS) [37-39]. NBS emphasize human-nature relationships, planning for adaptation, and resilience in a way that benefits humans and enhances biodiversity [40]. Such solutions cover a wide range of intervention approaches, including strictly green or combined green-grey infrastructure, ecosystem-based adaptation, and ecosystem-based risk management [39]. The NBS approach is relatively new in practice, and remains largely conceptual, with limited empirical applications or proven effectiveness. Early studies do strongly indicate that NBS approaches successfully mitigate environmental threats, promote resilience, and offer social, economic, and biotic rewards [37]. 
In the context of heat mitigation, NBS may be applied in either altering the existing built environment, or planning for future developments, both of which are achieved through the use of green infrastructure. The use of NBS interventions and analysis of the resulting microclimates offers a means for identifying specific applications at city-block scales, which provides evidence about the strengths/weaknesses of alternative development scenarios.

\section{Materials and Methods}

\subsection{Study Area}

The city of Portland is located in the Pacific Northwest region of the United States, and features a temperate, Mediterranean climate; summers are warm and dry, winters are mild and wet [41]. Historically, summer temperatures in Portland have been lower than those of typical Mediterranean climates (causing some to refer to the area as Cool-Mediterranean), although summer highs have been increasing each year since 2010. In 2017, a new record was set for days over 80 degrees Fahrenheit $\left[26.7^{\circ} \mathrm{C}\right]$ in the month of August (27 days), bypassing the previous record set just one year earlier. Also in 2017, the city experienced 24 days at or above 90 degrees Fahrenheit $\left[32.2^{\circ} \mathrm{C}\right]$, twice the normal value of 12 days per year [42]. Studying and preparing for changes in Portland's urban microclimate will be essential to maintaining resilience. Although the city has not had to contend much with urban heat in the past, conditions are shifting, and adaptive action will determine how well communities and infrastructure respond. Microclimate scenario modeling is a key first step in informing such action, and we draw on the specific climatic and physical characteristics of Portland, Oregon.

\subsection{Cluster Analysis}

Our initial assumption was that land-cover characteristics impact the success of urban heat mitigation strategies. A previous study of near surface air temperature in Portland, OR, examined various landscape features and their influence on summertime heat distribution [21]. Results of that study indicated that six variables could predict over $90 \%$ of the local variation in urban heat. For this study, the Portland metropolitan area was divided into groups based on those six land-cover variables: (1) percent of canopy, (2) percent of vegetation, (3) sum of biomass density, (4) mean building height, (5) total building volume, and (6) building height standard deviation.

Using these six variables, we divided the study area into grid cells and conducted a cluster analysis to delineate the landscape characteristics which help to explain the presence of UHI. Cluster analysis has been widely used for classification of digital images and allows us to reduce a large number of observations to a small set of similar groups to better understand the nature of landscape characteristics [43]. The clustering enables us to examine the effectiveness of mitigation strategies at distinct landscape features. Normal (Gaussian) mixture modeling is often used for cluster analysis [44], and was performed in the statistical programming environment $R$ using customized functions available from the MCLUST package [44]. MCLUST allows us to specify an integer vector specifying the numbers of mixture components (clusters) for which the Bayesian information criterion (BIC) [45] is to be calculated. Connors [46] claims that magnitude and pattern of land uses and covers may significantly influence urban heat, especially at micro $\left(\sim 100 \mathrm{~m}^{2}\right)$ to macro $\left(\sim 1 \mathrm{~km}^{2}\right)$ scales. Since our study focuses on neighborhood scale modeling, and average city block size in Portland (OR) ranges from 80-110 m [47], we selected $100 \mathrm{~m}$ grid size for this study. Based on preliminary studies, we selected seven clusters that distinguished residential areas from other landscape features, and eliminated three clusters: protected forest, water, and central business district. The eliminated areas reflect areas that are protected from development changes, and represent anomalies of urban land cover and land use. Non-eliminated portions of the study area were further divided into seven clusters by re-applying mixture modeling (Table 1). 
Table 1. Names and abbreviations of the seven cluster types used in microclimate modeling.

\begin{tabular}{ccc}
\hline Cluster Number & Name of Cluster Type & Abbreviation \\
\hline Cluster 1 & High-Canopy Neighborhood & HCN \\
Cluster 2 & Urban Districts and Corridors & UD \\
Cluster 3 & Medium-Canopy Neighborhood & MCN \\
Cluster 4 & Hardscaped Industrial & HI \\
Cluster 5 & Vegetated Urban & VU \\
Cluster 6 & Semi-Rural & SR \\
Cluster 7 & Hillside Forest & - \\
\hline
\end{tabular}

Based on the seven cluster types, six study sites were ultimately selected for microclimate modeling; no site was selected for cluster 7 , hillside forest, since no such area met the selection criteria. Criteria for site selection were as follows: (1) characteristics of the specified cluster type were represented; and (2) the site had been identified as an area of interest by local authorities. The study sites varied by cluster number, and represented a combination of several land-use and land-cover types, specifically those that were described by the city's Bureau of Planning and Sustainability as likely to undergo significant change in the coming years [48].

\subsection{Description of Simulation Tools}

For each of the six study sites, we used ENVI-met microclimate modeling to evaluate how different development patterns, including varying amounts of paving and vegetation, impact localized temperatures. ENVI-met (version 4.2.0), a computational fluid dynamics (CFD) model developed by Bruse [49], was used to simulate near-surface air temperature for six clusters in the study region. ENVI-met simulates the microclimatic dynamics within a daily cycle in complex urban structures, and its high spatial and temporal resolution enables a fine understanding of the microclimate at street level [35]. ENVI-met requires two input files: a configuration file, which specifies a setting for initialization values and timings, and an area input file, which specifies geometry of the model environment. Each of the aforementioned clusters was digitized as input for the model (Figure 1). The digitized imagery is represented by a color key as follows: grey $=$ buildings, green $=$ canopy and grass, black $=$ asphalt pavement, white $=$ concrete pavement, and brown $=$ loamy soils (Table 2$)$. Within each modeling site, we located five receptor points for close examination: center, east, west, north, and south. The results of these receptor points were used for model calibration, which is described in more detail at the following section. Average air temperature was calculated as the mean of air temperature of the whole domain. For the present study, heights of all buildings and trees were extracted from 2014 LiDAR data, which were available for the study region. The spatial resolution of ENVI-met ranges from 0.5 to $10 \mathrm{~m}$, with a maximum size of $100 \times 100$ grids for the basic version. We chose to employ $2 \mathrm{~m}$ horizontal resolution since the size of our largest study site (Cluster 4: Hardscaped Industrial) is approximately $180 \times 180 \mathrm{~m}(90 \times 90$ grids), making $2 \mathrm{~m}$ the highest possible resolution within software limitations. The vertical resolution was also set to $2 \mathrm{~m}$ with higher resolution of lower grids.

Table 2. Color key for ENVI-met input files shown in Figure 1.

\begin{tabular}{cc}
\hline Color & Corresponding Land Cover Type \\
\hline GREY & Buildings \\
GREEN & Trees and Grass \\
BLACK & Asphalt Pavement \\
WHITE & Concrete Pavement \\
BROWN & Loamy Soils \\
\hline
\end{tabular}




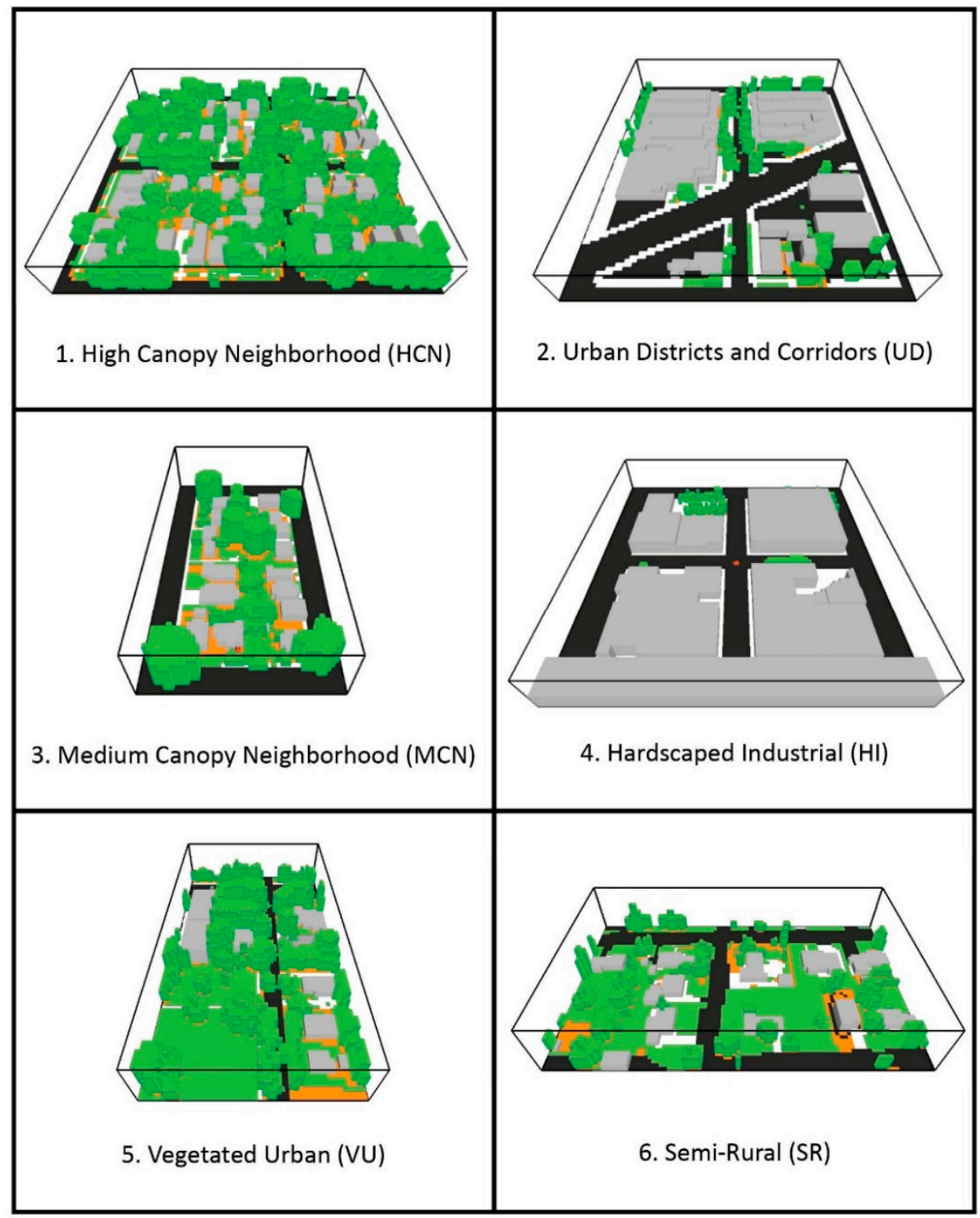

Figure 1. Input files for ENVI-met, representing the dominant land-use and/or land-cover types for each of the six selected study sites.

While the model has a large number of output parameters (e.g., wind speed, relative humidity, mean radiant temperature, etc.), air temperature is the one parameter that was investigated in this research. ENVI-met professional version offers an add-on post-processing tool, BioMet, to calculate several thermal comfort indices such as physiologically equivalent temperature (PET) and standard effective temperature (SET*). PET is a thermal index derived from the human energy balance and is well suited to the evaluation of the thermal component of different climates [50]. SET* is a comfort index, developed based on a dynamic two-node model of the human temperature regulation [51]. Although these indices are valid indicators of thermal comfort, we did not include them in our study and chose instead to examine only air temperature. Our goal was to compare differing greenspace configurations and surface materials for heat reduction potential, and air temperature is an appropriate indicator for that purpose. Furthermore, air temperature can be monitored easily at many locations throughout the year.

The model date was set for 18 August 2016, which was one of the warmest days of summer 2016. The model was digitized in ENVI-met with the current configuration of buildings and vegetation, and the initial climatic parameters were determined based on data from the nearest weather stations [52]. 
The 2016 weather data for Portland were obtained from the Weather Underground network. While the National Oceanic and Atmospheric Administration (NOAA) is believed to provide more reliable weather information, available data sets contain information only on daily maximum temperature, minimum temperature, and precipitation. The Weather Underground network, used for this study, provides hourly accounts of temperature, precipitation, humidity and wind speed, and it has been extensively used by researchers for examining the impacts of weather on transit activities [53-56].

We calibrated the model using air temperature at the height of $1.4 \mathrm{~m}$ as that is the height of the nearest weather station, and approximates potential exposure to people at ground level. The distance between the study sites and the nearest weather stations varied from $35 \mathrm{~m}$ to $800 \mathrm{~m}$. Input parameters such as initial temperature, wind speed, and humidity were adjusted for each run until graphs of the modeled temperatures and measured temperatures become comparable (Table 3). Many parameters were chosen based on ENVI-Met default values and weather station data, though these were subsequently refined to establish the most accurate parameters for the study area. Pearson's correlation coefficients between measured temperatures and modeled temperatures were calculated, and the results for clusters 1 through 6 were $0.76,0.66,0.93,0.68,0.81$, and 0.75 , respectively. For further validation, we extracted $1.4 \mathrm{~m}$ air temperature from ENVI-met simulation results at 7:00 and 15:00 PST. Table 4 shows the difference between simulated and measured mean air temperature for each scenario. Although the model tends to overestimate the air temperature in the morning, the error in the afternoon is between -0.6 and 1.7 degrees Celsius (Table 4). Since we are more interested in the temperature difference between scenarios, these errors do not affect our calculations of temperature difference.

Table 3. Input and output parameters used in model calibration and resulting values. This table represents the calibration of Cluster $3(\mathrm{MCN})$ and serves as a sample for reference, though similar tables were generated for all six cluster types.

\begin{tabular}{ccc}
\hline Parameter & Initial Value & Final Value \\
Wind speed $(\mathrm{m} / \mathrm{s})$ & 1.7 & 1.7 \\
Wind direction & $315(\mathrm{NNW})$ & $315(\mathrm{NNW})$ \\
Roughness length & 0.01 & 0.1 \\
Initial temperature of atmosphere $(\mathrm{C})$ & 26 & 30 \\
Specific humidity at model top $(2500 \mathrm{~m}, \mathrm{~g} / \mathrm{kg})$ & 5 & 2 \\
Relative humidity & 60 & 30 \\
Forcing & No & No \\
humidity & Open & Open \\
Lateral Boundary Conditions (LBC) for temperature, & Forced & 300 \\
LBC for Turbulence & 293 & 300 \\
Initial temperature upper layer $(0-20 \mathrm{~cm})[\mathrm{K}]$ & 293 & 300 \\
Initial temperature middle layer $(20-50 \mathrm{~cm})[\mathrm{K}]$ & 293 & 50 \\
Initial temperature deep layer $(50-200 \mathrm{~cm})[\mathrm{K}]$ & 50 & 60 \\
Relative humidity upper layer $(0-20 \mathrm{~cm})$ & 60 & 60 \\
Relative humidity middle layer $(20-50 \mathrm{~cm})$ & 60 & 60 \\
Relative humidity deep layer $(50-200 \mathrm{~cm})$ & 60 & \\
Relative humidity bedrock layer $($ below $200 \mathrm{~cm})$ & &
\end{tabular}

Table 4. Temperature difference between simulated mean air temperature of each cluster, and the air temperature at nearest weather stations (degree Celsius).

\begin{tabular}{ccccccc}
\hline Time of the Day & HCN & UD & MCN & HI & VU & SR \\
\hline Morning (7:00 PST) & 5.9 & 0.7 & 7.3 & 4.5 & 6.4 & 6.5 \\
Afternoon (15:00 PST) & 0.2 & 0.1 & 1.3 & -0.6 & -0.6 & 1.7 \\
\hline
\end{tabular}

\subsection{Scenario Development}

Once the model was calibrated, we simulated diverse scenarios to evaluate how different landscape features affect ambient temperature. The scenarios (also referred to as heat mitigating interventions) 
used for this research were developed with input from urban planners at the City of Portland, as well as previously published studies [36,57-62]. While the urban planners offered insights about the plausibility of scenarios (what city codes would allow), the published research helped to calibrate specifics of the ENVI-Met model. For example, the City of Portland recently passed a resolution requiring green roofs on all new developments, which helped us identify relevant literature. Taleghani et al. [60] examined the effect of cool roofs, cool pavement, green roofs and trees on pedestrian thermal comfort using micrometeorological simulations. In addition to "cool" materials, Taleghani et al. simulated an increase in roof and asphalt albedo of 0.3 (Roof: $0.1 \rightarrow 0.4$, Asphalt pavement: $0.2 \rightarrow 0.5$ ), representing the upper bound values for what is currently technologically feasible. Al-hafiz et al. [63] examined the impact of changes in albedo on surface and air temperatures, simulating an increase in rooftop albedo from 0.25 to 0.8 . Following the model used by Taleghani et al. in this study, we chose to simulate an increase in albedo of 0.3 for both roofs and pavement, resulting in the following values: asphalt shingle (roof) $=0.5$, concrete with filled block (roof) $=0.6$, and asphalt pavement $=0.5$. We simulated the addition of green roofs, modeling $100 \%$ coverage with $50 \mathrm{~cm}$ grasses. The AddGreen scenario simulated trees in areas where adequate space was available, and grasses in areas where it was not; an example of this modeled scenario is available in Figure 2. A total of six simulated interventions were developed (Table 5), and each was applied to the six development type clusters, resulting in a total of 36 possible effects on temperatures.

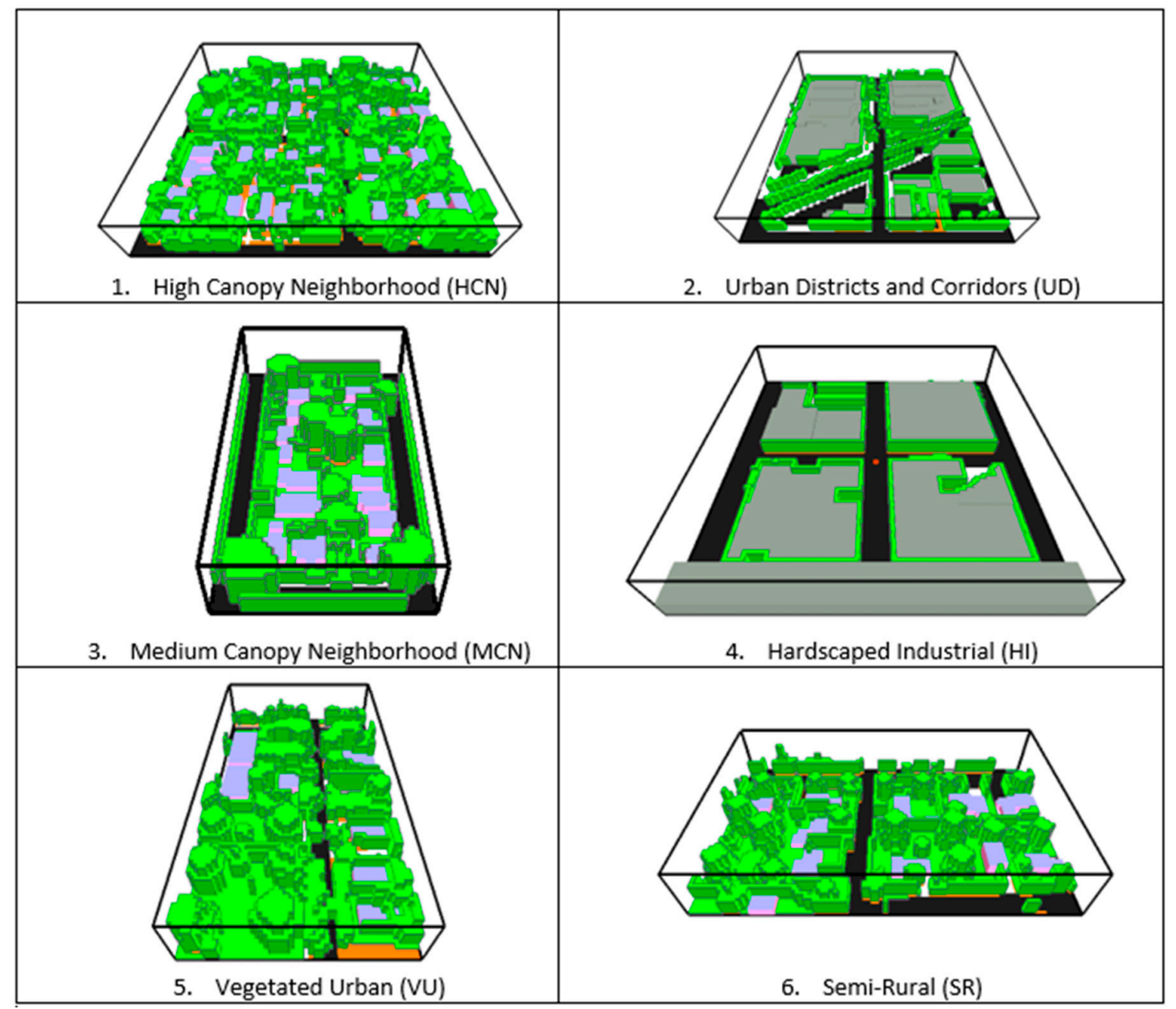

Figure 2. Input files for ENVI-met, representing the dominant land-use and/or land-cover types for each of the six selected study sites for "AddGreen" scenario. 
Table 5. The seven scenarios modeled for each of the six cluster types. These include the base scenario, for which no changes were simulated and to which other scenarios were compared, as well as six design interventions.

\begin{tabular}{|c|c|}
\hline Scenario Name & Scenario Description \\
\hline Base & Base model; no changes simulated \\
\hline NoGreen & No greenspace; any existing greenspace or soils are replaced with asphalt \\
\hline AddGreen & $\begin{array}{l}\text { Add trees along sidewalks and parking lots; add grass and trees with sizing } \\
\text { relevant for spaces on exposed soil }\end{array}$ \\
\hline GreenRoof & Apply green roof $(100 \%$ coverage with $50 \mathrm{~cm}$ grass $)$ to all buildings \\
\hline RoofAlbedo & Increase albedo of all roofs by 0.3 \\
\hline RoadAlbedo & Increase albedo of asphalt pavements by 0.3 \\
\hline Combination & Combined use of the AddGreen, RoofAlbedo and RoadAlbedo scenarios \\
\hline
\end{tabular}

\section{Results}

A map of all clusters was developed to identify potential locations of interest to this study; final site selections are marked with black dots and labeled on the map (Figure 3). There is considerable mixing of cluster types across the city, although for the purpose of modeling scenarios we sought out study sites that contain primarily one cluster type. Data ranges for all input variables, for the six final cluster selections, are available below (Figure 4). Emphasizing the effects of heat-ameliorating scenarios on specific cluster types, we created a generalizable model that may be applied to those land cover types throughout the city.

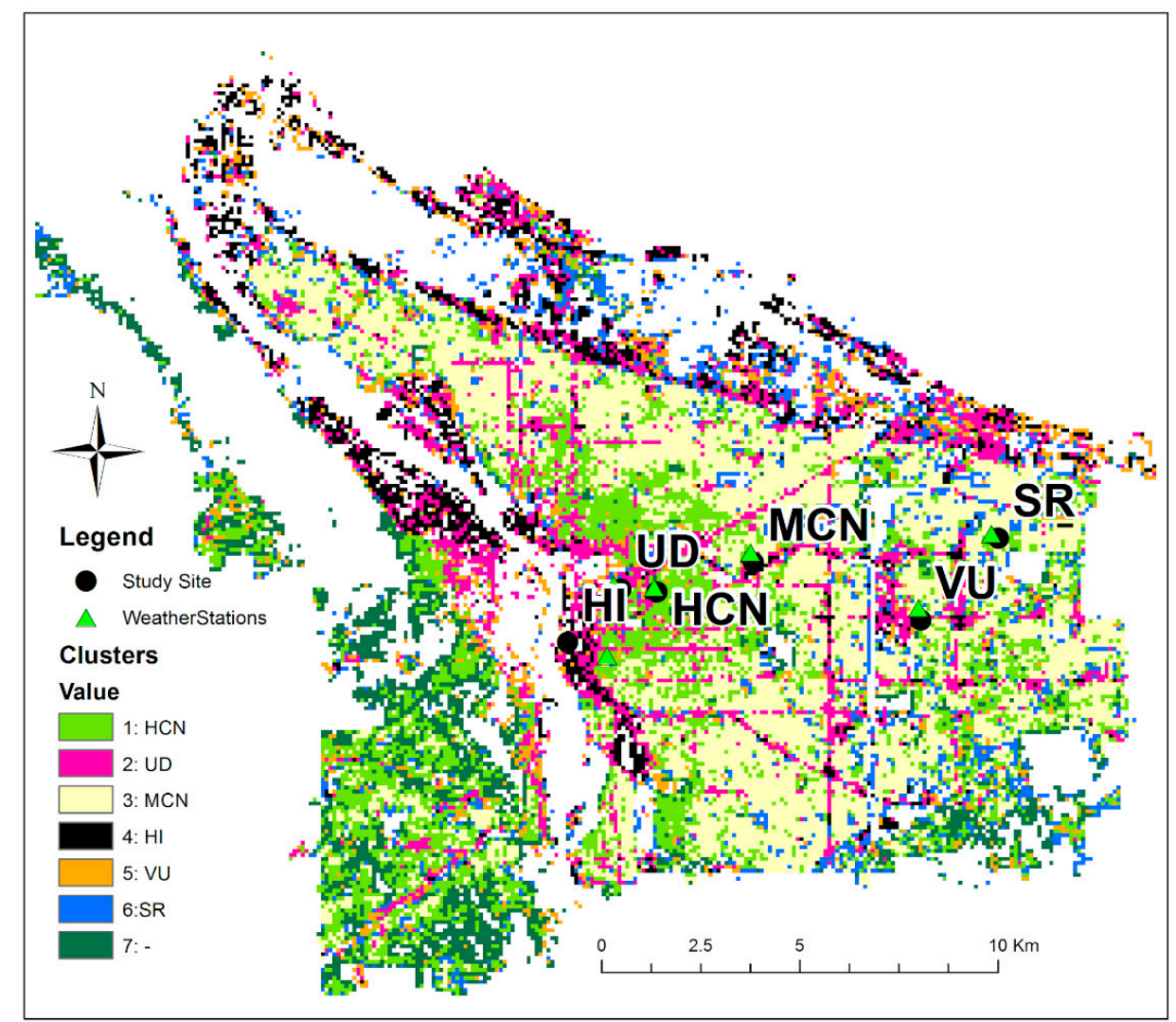

Figure 3. Locations of the seven clusters (as identified in Table 1), the six study sites that were ultimately selected for analysis, and the sites of the weather stations. No site was chosen for cluster 7, hillside forest, since no such area met the selection criteria. 

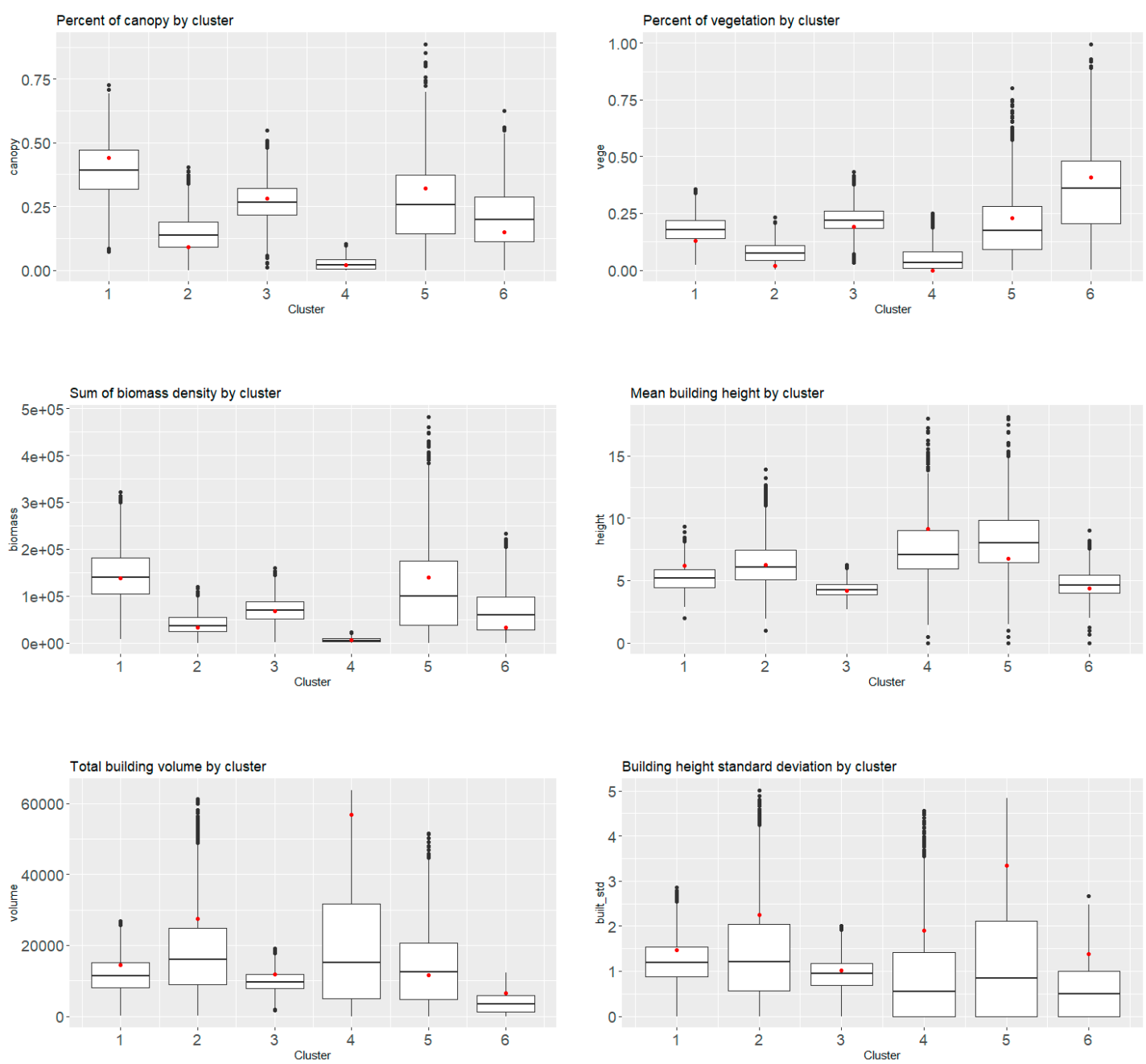

Figure 4. Data ranges for seven input variables, for each of the six final cluster selections. Red dots indicate the value for each study site.

By simulating these different scenarios on the six clusters, we determined the extent to which landscape changes are expected to alter ambient temperature. The results of all six scenario simulations, within the context of the six cluster areas, are analyzed in contrast to the base scenario, in which no green infrastructural changes were considered. Based on our results, maximum temperatures were observed around 3 PM for the study region, and this time was used for comparison across all the scenarios. Temperature changes for each scenario reflect positive, neutral, and negative changes for each (Table 6, Figure 5).

Table 6. Average air temperature difference relative to the Base scenario, at $3 \mathrm{PM}$, at $1.4 \mathrm{~m}$ height.

\begin{tabular}{ccccccc}
\hline \multirow{2}{*}{ Cluster } & \multicolumn{5}{c}{ Heat Mitigation Scenarios (Temperature Change in ${ }^{\circ} \mathbf{C}$ ) } \\
\cline { 2 - 6 } & NoGreen & AddGreen & GreenRoof & RoofAlbedo & RoadAlbedo & Combination \\
\hline HCN & +6.9 & -0.5 & -0.1 & -0.2 & -0.2 & -0.7 \\
UD & +1.6 & -1.5 & -0.5 & -1.2 & -1.0 & -3.4 \\
MCN & +3.4 & -1.5 & -0.1 & -0.2 & -0.8 & -2.2 \\
HI & +0.5 & -1.0 & -0.4 & -1.4 & -0.9 & -3.2 \\
VU & +6.6 & -1.1 & 0.0 & -0.2 & -0.5 & -1.7 \\
SR & +3.9 & -2.6 & -0.1 & -0.2 & -0.8 & -3.3 \\
\hline
\end{tabular}




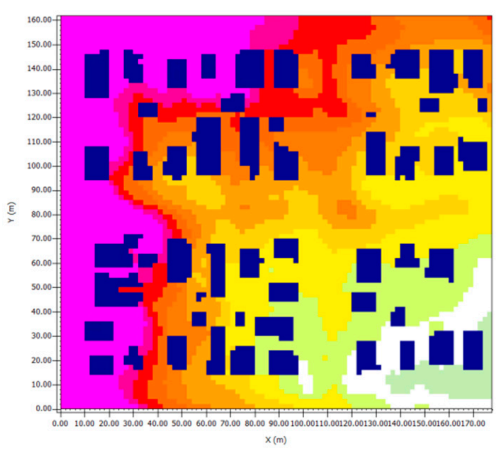

1. High-Canopy Neighborhood (HCN)

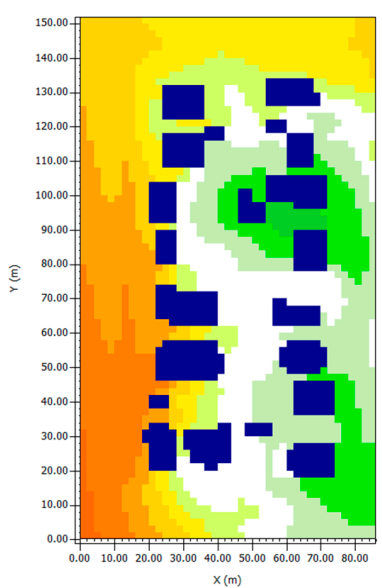

3. Medium-Canopy Neighborhood (MCN)

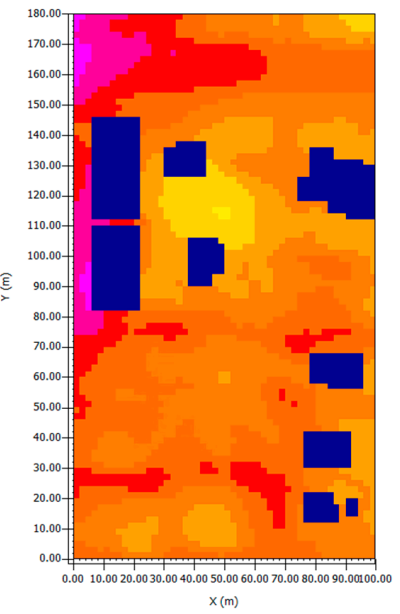

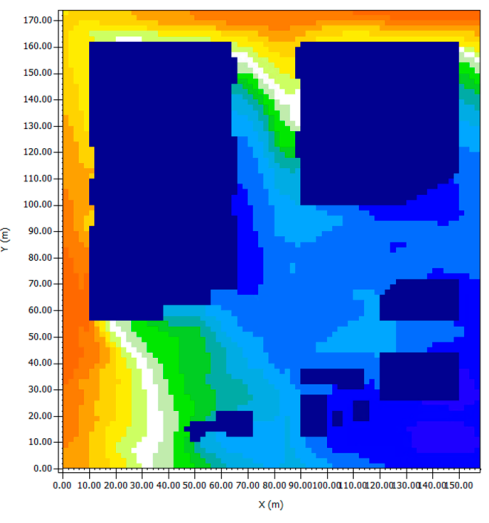

2. Urban Districts and Corridors (UD)

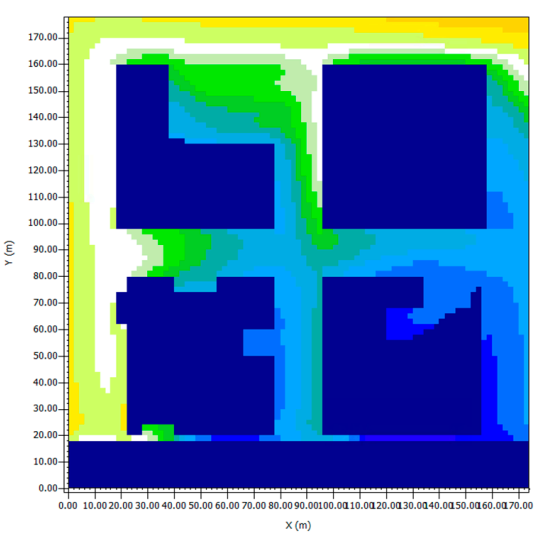

4. Hardscaped Industrial (HI)

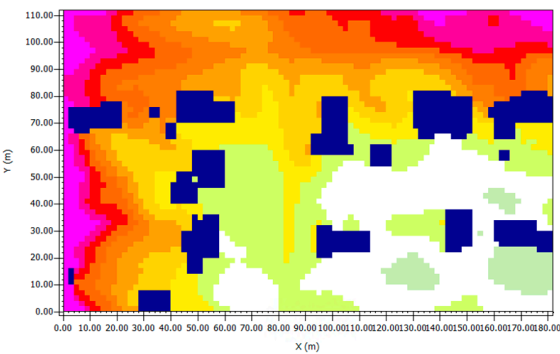

6. Semi-Rural (SR)

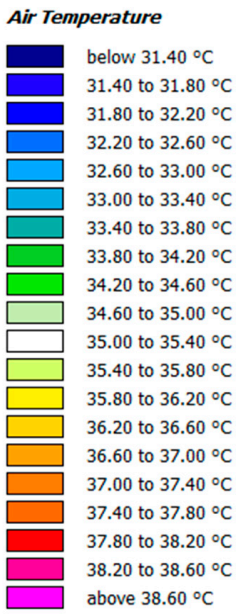

5. Vegetated Urban (VU)

Figure 5. Simulated air temperature (in ${ }^{\circ} \mathrm{C}$ ) at $3 \mathrm{PM}, 1.4 \mathrm{~m}$ height for the Combination scenario.

The NoGreen scenario increased temperature significantly for $\mathrm{HCN}\left(+6.9^{\circ} \mathrm{C}\right)$ and $\mathrm{VU}\left(+6.6^{\circ} \mathrm{C}\right)$, but had a lesser impact for $\mathrm{SR}\left(+3.9^{\circ} \mathrm{C}\right), \mathrm{MCN}\left(+3.4^{\circ} \mathrm{C}\right), \mathrm{UD}\left(+1.6^{\circ} \mathrm{C}\right)$ and $\mathrm{HI}\left(+0.5^{\circ} \mathrm{C}\right)$. The most significant increases were in land use categories that already had a lot of vegetation, and the least increase were in those locations with least. These results may suggest the importance of tree preservation programs, which we will discuss further in the Discussion section below. 
The AddGreen scenario showed cooling capability in all cluster types, with the greatest cooling effect for SR $\left(-2.6^{\circ} \mathrm{C}\right)$, and least for $\mathrm{HCN}\left(-0.5^{\circ} \mathrm{C}\right)$. Not surprisingly, areas of the city with lots of vegetation do not change in temperature when adding more trees, in part because available space for tree planting is limited and/or already taken by other vegetation.

The RoofAlbedo scenario was shown to be most effective in UD $\left(-1.2^{\circ} \mathrm{C}\right)$ and $\mathrm{HI}\left(-1.4^{\circ} \mathrm{C}\right)$, while RoadAlbedo had the greatest cooling effects in $\mathrm{MCN}\left(-0.8^{\circ} \mathrm{C}\right)$, VU $\left(-0.5^{\circ} \mathrm{C}\right)$, and $\mathrm{RF}\left(-0.8^{\circ} \mathrm{C}\right)$. Both interventions showed a measurable decrease in temperature within all cluster types.

Overall, the GreenRoof scenario had the lowest impact on ambient temperature, in some cases having no effect at all (VU) or decreasing temperature only a meager amount (HCN, MCN, SR). UD and $\mathrm{HI}$ are the only cluster types in which this type of green roof appears successful as a tool for heat mitigation, with results of $-0.5^{\circ} \mathrm{C}$ and $-0.4^{\circ} \mathrm{C}$, respectively.

Across all cluster types, the Combination scenario was by far the most effective at reducing ambient temperature, when compared to the use of any single solution. However, as with all scenarios tested, changes in temperature varied significantly from cluster to cluster. While in UD, HI and SR, the Combination scenario resulted in an impressive average temperature decrease of over $3^{\circ} \mathrm{C}$, the results for $\mathrm{HCN}$ were a relatively small $-0.7^{\circ} \mathrm{C}$.

These results suggest that increasing vegetation, decreasing the amount of asphalt pavement, and heightening albedo of both roof and paved surfaces have the potential to reduce ambient temperature; however, the effectiveness of each strategy varies depending on the land-cover cluster type to which it is applied. Furthermore, these results suggest that removing vegetation (the NoGreen scenario) is expected to result in measurable temperature increases in all cluster types; these increases can be dramatic, as shown in the cases of HCN and VU. This particular result indicates not only the cooling effect of vegetation, but also the heating effect of asphalt, a material which we associate with the presence of UHI in Portland, OR.

\section{Discussion}

This study aimed to identify which built environment characteristics are associated with high urban temperatures, as well as the extent to which alternative, and/or green designs might reduce temperatures and the UHI effect. Microclimate modeling was performed for six land-cover cluster types within the city of Portland, OR, referencing the unique climatic and physical environmental characteristics of the region. Results show that asphalt is a material highly associated with an increase in ambient temperature, while all green and green-grey infrastructure interventions, including green roofs, heightened road and roof albedo, and ground-level vegetation exhibit potential to mitigate that effect. Although all intervention scenarios modeled suggested a positive impact on urban cooling, particularly the Combination scenario, they were also shown to be inconsistently effective across land-cover cluster types.

Given that each cluster type is assumed to offer a unique baseline of vegetation, it is unsurprising that the different scenarios exhibit varying degrees of influence. For example, the NoGreen scenario produced a dramatic change in the VU cluster $\left(+6.6^{\circ} \mathrm{C}\right)$, but a comparatively negligible change in $\mathrm{HI}\left(+0.5^{\circ} \mathrm{C}\right)$. This difference is likely to do with the amount of vegetation present in each cluster type prior to scenario modeling. VU areas are well vegetated and, thus, may be drastically affected by the loss of that vegetation; by contrast, $\mathrm{HI}$ areas are largely unvegetated to begin with, and thus unsusceptible to major changes under the same modeled conditions. Differences in baseline vegetation or green infrastructure may similarly explain variation in the effectiveness of cooling strategies. Adding ground-level vegetation (AddGreen) in a UD cluster is shown to be more cooling than the same intervention in VU $\left(+1.5^{\circ} \mathrm{C}\right.$ and $+1.1{ }^{\circ} \mathrm{C}$, respectively). Again, as the VU cluster is already well-vegetated, there is less benefit to be gained by adding vegetation; conversely, the UD cluster is not especially green to begin with, and allows more room for improvement. There does appear to be a limit to the cooling potential of vegetation, however, namely in the HI cluster. While UD, the second most grey infrastructural environment, seems to respond well to increased vegetation, the HI landscape is 
less affected; we speculate that this is due to the overwhelming domination of grey infrastructure in $\mathrm{HI}$ clusters, the heating power of which is not correctable by ground-level vegetation alone.

The HCN land cover cluster represents neighborhoods with dense tree cover already present, and exhibited some of the most severe results in modeling. The NoGreen scenario proved most impactful for $\mathrm{HCN}$, increasing ambient temperature by an average $6.9^{\circ} \mathrm{C}$, while all other scenarios (AddGreen, GreenRoof, RoadAlbedo, RoofAlbedo) were only minimally successful. Indeed, the Combination scenario was nearly five times more effective in UD than in HI, which indicated the smallest cooling result for that scenario. As with the previous examples given, these results are unsurprising considering the thick baseline vegetation available in $\mathrm{HCN}$. However, what is unique to $\mathrm{HCN}$ are recommendations for future planning. For other cluster types, we recommend the implementation of additional vegetation, green roofs, or high albedo surfaces, all of which are expected to offer significant cooling benefits. In HCN areas, existing vegetation offers more such benefits than any other modeled scenario; therefore, we recommend an emphasis on canopy maintenance for these areas, and policies that protect degradation of existing vegetation.

The MCN cluster type is of particular interest to this study because it accounts for the largest portion of the urban study area, at $33 \%$. Results show that these neighborhoods can be cooled most effectively by adding trees and heightening road albedo. This kind of landscape provides a special challenge in terms of future development, given that these areas are expected to increase in size and density within Portland [44]. As a direction for future research, it would be helpful to conduct additional microclimate modeling that considers changes in building density; this will allow researchers to determine whether pre-development temperatures can be maintained in spite of growing density, and the extent to which green solutions would need to be employed to offset any increases in heat. While this additional research would be enlightening across all land-cover cluster types, MCN represents an area deserving more urgent attention, as it is both fast-growing and serves as home to many residents.

Green roofs are a much-discussed strategy for heat mitigation, although our results show that they are only convincingly effective in highly built-out areas, particularly those with large amounts of roof space, as well as grey infrastructure, such as HI and UD. This does not mean that green roofs could not offer heat-mitigating potential in other land-cover areas, but does suggest that this strategy would be most successful in these particular settings. However, the results also show that in all cluster types, the benefits offered by heightening roof albedo are more effective than installing green roofs. As this is likely to be a less expensive intervention and require less maintenance over time [64], practitioners may wish to prioritize lightened roofs over green roofs, achieving the same heat-reduction benefits at a lower cost. An argument in favor of green roofs is the fact that they fill environmental roles beyond heat mitigation, such as stormwater retention, pollution control, and habitat for wildlife [65]. It will be up to planners to set priorities and reconcile tradeoffs accordingly when choosing between these two types of roof design.

\subsection{Relationship to Previous Studies}

According to Liu et al. [66], key elements thought to reduce land-surface temperature differ by "climatic regions, seasons and spatial scales, and also vary according to the statistical methods used for analysis." Liu et al.'s conclusion supports the notion, central to this study, that all green designs or alterations to the built environment are not consistently effective, and that intra-urban variations make a difference to temperature outcomes. That said, there are some recurring themes throughout the literature on this topic that are generally supported by our results in Portland, Oregon.

Many studies of land surface temperature in urban areas have revealed the apparent cooling effects of green spaces and vegetation [67-71], as found in the present study. Taleghani et al.'s studies in both Los Angeles [60] and Portland [62] show that adding vegetation and increasing the albedo of the pavement can decrease air temperature at $1.5 \mathrm{~m}$. The Los Angeles study [60] shows that green roofs specifically (as opposed to ground-level vegetation) have little cooling effect at $1.5 \mathrm{~m}$ height, but 
mainly provide cooling effects at heights above the pedestrian level (rooftop level). Similarly, Skelhorn et al. [36] found that air temperature decreased slightly, by up to $0.17^{\circ} \mathrm{C}$, only at roof level $(4 \mathrm{~m})$ when applying the green roof scenario in Manchester, UK. By contrast, Peng and Jim [72] suggest that extensive implementation of green roofs does reduce pedestrian-level air temperature by $0.4-0.7^{\circ} \mathrm{C}$ in Hong Kong. The present study aligns more closely with conclusions by Taleghani et al. and others who suggest that green roofs have minimal impact at the pedestrian level. In our study, the GreenRoof intervention is consistently the least effective in all modeled scenarios (at $1.4 \mathrm{~m}$ height), although we did not model its effects at roof level. Differences in expected effectiveness of green roofs may have much to do with variation in regional climates, as suggested by Morakinyo et al. [61].

Other studies have focused specifically on apparent relationships between urban temperature and the configuration of green space. For example, Naeem [73] argues that green spaces with a square shape, less fragmentation, and a greater percentage of vegetation contribute to reducing the surface temperature in Beijing, China, and Islamabad, Pakistan. While configuration was not a central focus of this study, results from the HI cluster do show that adding vegetation in a predominantly linear pattern has minimal cooling effect. However, the Combination scenario of cooling interventions (rather than AddGreen alone) showed the most dramatic effects in the HI and UD clusters. This outcome supports a claim by Peng [74] that built-up areas and non-vegetated land will be most significantly affected by cooling measures. Finally, our results support those from previous research $[75,76]$ which find high-albedo surfaces to be viable cooling options. While our results do generally echo broad thematic findings of previous studies, they advance research on the topic by showing specific temperature changes, by intervention type, for various intra-urban land cover clusters.

\subsection{Nature-Based Designs}

Increasingly, environmental researchers and practitioners are approaching natural resource management, climate resiliency, and adaptation with an eye toward solutions that work with, rather than against or separately from, natural processes. Nature-based solutions can take many forms, in many environments, although the underlying goals include social and biotic resilience, equitable adaptation, and functional human-nature relationships $[39,40]$. The use of green infrastructure interventions as a solution to the UHI effect has the power to hit all of the aforementioned marks, while correcting existing imbalances in the built environment. Previous studies of Portland have shown the built environment to be highly variable, and heat distribution inconsistent across space [21,77]. While some neighborhoods, mainly those with higher-income residents, reap the benefits of copious tree cover, the city's lower income and non-white residents are exposed to disproportionately high temperatures [77]. The use of vegetation to cool these hottest areas may provide other benefits such as air quality improvement and aesthetic benefits, economic value, increased habitat for birds and other wildlife, increased biodiversity (assuming diverse tree and grass species are selected), and overall human and biotic resilience in the age of climate change and global warming [78,79]. Even nature-based interventions which do not involve the use of vegetation, such as roof and road lightening, can offer an improved quality of human life via citywide cooling, while preventing the loss of sensitive species to extreme heat stress. It is in the best interest of humanity to conserve and bolster the capacity of our environments to offer the ecosystem services on which we depend for survival, and this ethic certainly applies in the struggle for cool, healthy, resilient urban areas.

\subsection{Transferability of the Study}

As the results of this study have shown, green and nature-based interventions are not equal across a city, and different land-cover types significantly alter the usefulness of different strategies. The local value of this study to City of Portland officials and planning practitioners is that it reveals those differences, and can guide informed action at a level more granular than the typical citywide scale. Just as we see differences in the efficacy of these interventions across one city, we would expect to see differences across multiple cities and various climates. As such, we do not recommend that these 
results be applied as they are to any city other than Portland, OR. However, a benefit of this ENVI-met modeling approach is that the same steps outlined here may be followed and replicated anywhere, made specific to any location by inputting the relevant climate and land-use data. There are numerous studies available which report on the average cooling capacity of various interventions discussed here, though these notably do not account for the unique intra-urban climate or physical environment of a particular place. Rather than rely on generalized averages, we recommend any practitioners with an interest in urban heat reduction to model proposed scenarios at this intra-urban scale for the most relevant results.

\section{Conclusions}

This study examined the impact of vegetation and building materials on ambient air temperature using ENVI-met microclimate modeling. The results indicate that decreasing paved surfaces, increasing vegetation, and heightening road and roof albedo can maintain or reduce temperatures in any of the areas studied. We observed that different areas of the city require site-specific applications for reducing temperatures. Areas mostly covered by buildings and pavement, such as Urban Districts and Hardscape Industrial, will be cooled by increasing the albedo of roofs and roads. On the other hand, for the areas that already feature abundant tree cover, such as High-Canopy Neighborhoods and Vegetated Urban, planning efforts should focus on maintaining the status quo rather than adding vegetation or increasing albedo. In areas with large open spaces of soils or grasses, such as Semi-Rural, temperature may be successfully reduced by simply adding more trees. Medium-Canopy Neighborhoods, which occupy the largest portion of the study area, would benefit by adding trees in open spaces and increasing the albedo of roads. No matter the intervention recommended for each cluster type, this study has offered compelling evidence that nature-based, green solutions to the UHI effect are both practical and promising. Green infrastructure is not only cooling, but offers social and biotic rewards far beyond what is currently offered by many areas of the built urban environment. Local leaders, planners and policymakers have an imperative to look ahead, consider the limits of adaptation, and make responsible choices that will promote human and environmental resilience as we all face a warming world.

Author Contributions: Y.M. conceived of and performed the experiments, analyzed results, and wrote the Methods and Results sections. V.S. conceived of the research, developed the research questions, and organized the overall manuscript. V.S. and D.H. wrote the Introduction, Discussion and Conclusions sections of the manuscript, edited the Methods and Results sections, and contributed substantially to the packaging and formatting of information.

Funding: This research was funded by the U.S. Forest Service's National Urban and Community Forestry Challenge Grant (No. 17-DG-11132544-014), and the National Science Foundation's Sustainable Research Network Grant (No. 1444755).

Acknowledgments: This research was made possible with support from the Institute of Sustainable Solutions at Portland State University, and the James F. and Marion L. Miller Foundation. Publication of this article in an open access journal was funded by the Portland State University Library's Open Access Fund.

Conflicts of Interest: The authors declare no conflict of interest. The funders had no role in the design of the study; in the collection, analyses, or interpretation of data; in the writing of the manuscript, or in the decision to publish the results.

\section{References}

1. Mote, P.W.; Salathé, E.P., Jr. Future climate in the Pacific Northwest. Clim. Chang. 2010, 102, 29-50. [CrossRef]

2. Meehl, G.A.; Tebaldi, C. More intense, more frequent, and longer lasting heat waves in the 21st century. Science 2004, 305, 994-997. [CrossRef] [PubMed]

3. Hayhoe, K.; Wuebbles, D.J.; Easterling, D.R.; Fahey, D.W.; Doherty, S.; Kossin, J.; Sweet, W.; Vose, R.; Wehner, M. Capter 2: Our Changing Climate. In Impacts, Risks, and Adaptation in the United States: Fourth National Climate Assessment; Reidmiller, D.R., Avery, C.W., Easterling, D.R., Kunkel, K.E., Lewis, K.L.M., Maycock, T.K., Stewart, B.C., Eds.; U.S. Global Change Research Program: Washington, DC, USA, 2018; Volume II, pp. 72-144. [CrossRef] 
4. Zhang, K.; Chen, T.H.; Begley, C.E. Impact of the 2011 heat wave on mortality and emergency department visits in Houston, Texas. Environ. Health 2015, 14, 1-7. [CrossRef] [PubMed]

5. Knowlton, K.; Rotkin-Ellman, M.; King, G.; Margolis, H.G.; Smith, D.; Solomon, G.; Trent, R.; English, P. The 2006 California heat wave: Impacts on hospitalizations and emergency department visits. Environ. Health Persp. 2009, 117, 61-67. [CrossRef] [PubMed]

6. Dhainaut, J.F.; Claessens, Y.E.; Ginsburg, C.; Riou, B. Unprecedented heat-related deaths during the 2003 heat wave in Paris: Consequences on emergency departments. Crit. Care 2003, 8, 1-2. [CrossRef]

7. Klinenberg, E. Denaturalizing disaster: A social autopsy of the 1995 Chicago heat wave. Theory Soc. 1999, 28, 239-295. Available online: https://www.jstor.org/stable/3108472 (accessed on 22 October 2018). [CrossRef]

8. Smoyer-Tomic, K.E.; Kuhn, R.; Hudson, A. Heat wave hazards: An overview of heat wave impacts in Canada. Nat. Hazards 2003, 28, 465-486. [CrossRef]

9. Huang, G.; Zhou, W.; Cadenasso, M.L. Is everyone hot in the city? Spatial pattern of land surface temperatures, land cover and neighborhood socioeconomic characteristics in Baltimore, MD. J. Environ. Manag. 2011, 92, 1753-1759. [CrossRef]

10. Graham, J.D.; Chang, B.H.; Evans, J.S. Poorer is riskier. Risk Anal. 1992, 12, 333-337. [CrossRef]

11. Gronlund, C.J.; Zanobetti, A.; Schwartz, J.D.; Wellenius, G.A.; O'Neill, M.S. Heat, heat waves, and hospital admissions among the elderly in the United States, 1992-2006. Environ. Health Perspect. 2014, 122, 1187-1192. [CrossRef]

12. Åströma, D.O.; Forsberg, B.; Rocklövab, J. Heat wave impact on morbidity and mortality in the elderly population: A review of recent studies. Maturitas 2011, 69, 99-105. [CrossRef] [PubMed]

13. Howard, L. The Climate of London: Deduced from Meteorological Observations Made at Different Places in the Neighbourhood of the Metropolis; W. Phillips: London, UK, 1820; ISBN 978-144-602-480-5.

14. Peng, S.; Piao, S.; Ciais, P.; Friedlingstein, P.; Ottle, C.; Bréon, F.; Nan, H.; Zhou, L.; Myneni, R.B. Surface urban heat island across 419 global big cities. Environ. Sci. Tech. 2012, 46, 696-703. [CrossRef]

15. Debbage, N.; Shepherd, J.M. The urban heat island effect and city contiguity. Comput. Environ. Urban 2015, 54, 181-194. [CrossRef]

16. Voogt, J.A.; Oke, T.R. Thermal remote sensing of urban climates. Remote Sens. Environ. 2003, 86, 370-384. [CrossRef]

17. Seto, K.C.; Shepherd, J.M. Global urban land-use trends and climate impacts. Curr. Opin. Environ. Sustain. 2009, 1, 89-95. [CrossRef]

18. Baldinelli, G.; Bonafoni, S. Analysis of Albedo Influence on Surface Urban Heat Island by Spaceborne Detection and Airborne Thermography. In International Conference on Image Analysis and Processing; Springer: Cham, Switzerland, 2015.

19. Takebayashi, H.; Moriyama, M. Study on the urban heat island mitigation effect achieved by converting to grass-covered parking. Sol. Energy 2009, 83, 1211-1223. [CrossRef]

20. Hamdi, R.; Schayes, G. Sensitivity study of the urban heat island intensity to urban characteristics. Int. J. Climatol. 2008, 28, 973-982. [CrossRef]

21. Voelkel, J.; Shandas, V. Towards systematic prediction of urban heat islands: Grounding measurements, assessing modeling techniques. Climate 2017, 5, 41. [CrossRef]

22. United Nations Department of Economic and Social Affairs, Population Division. World urbanization prospects: The 2014 revision. Available online: http://esa.un.org/unpd/wup/Publications/Files/WUP2014Report.pdf (accessed on 7 October 2018).

23. Gunawardenaa, K.R.; Wellsb, M.J.; Kershawa, T. Utilising green and bluespace to mitigate urban heat island intensity. Sci. Total Environ. 2017, 584-585, 1040-1055. [CrossRef]

24. Aflakia, A.; Mirnezhada, M.; Ghaffarianhoseinibg, A.; Ghaffarianhoseini, A.; Omranyd, H.; Wange, Z.; Akbarif, H. Urban heat island mitigation strategies: A state-of-the-art review on Kuala Lumpur, Singapore and Hong Kong. Cities 2017, 62, 131-145. [CrossRef]

25. Santamouris, M.; Ding, L.; Fiorito, F.; Oldfield, P.; Osmond, P.; Paolini, R.; Prasad, D.; Synnefa, A. Passive and active cooling for the outdoor built environment-Analysis and assessment of the cooling potential of mitigation technologies using performance data from 220 large scale projects. Sol. Energy 2017, 154, 14-33. [CrossRef]

26. Santamouris, M.; Synnefa, A.; Karlessi, T. Using advanced cool materials in the urban built environment to mitigate heat islands and improve thermal comfort conditions. Sol. Energy 2011, 85, 3085-3102. [CrossRef] 
27. Younger, M.; Morrow-Almeida, H.R.; Vindigni, S.M.; Dannenberg, A.L. The built environment, climate change, and health: Opportunities for co-benefits. Am. J. Prev. Med. 2008, 35, 517-526. [CrossRef] [PubMed]

28. Hart, M.A.; Sailor, D.J. Quantifying the influence of land-use and surface characteristics on spatial variability in the urban heat island. Theor. Appl. Climatol. 2009, 95, 397-406. [CrossRef]

29. Susca, T.; Gaffin, S.R.; Dell'Osso, G.R. Positive effects of vegetation: Urban heat island and green roofs. Environ. Pollut. 2011, 159, 2119-2126. [CrossRef] [PubMed]

30. Upreti, R.; Wang, Z.; Yang, J. Radiative shading effect of urban trees on cooling the regional built environment. Urban For. Urban Green. 2017, 26, 18-24. [CrossRef]

31. Oliveira, S.; Andrade, H.; Vaz, T. The cooling effect of green spaces as a contribution to the mitigation of urban heat: A case study in Lisbon. Build. Environ. 2011, 46, 2186-2194. [CrossRef]

32. Santamouris, M. Cooling the cities-A review of reflective and green roof mitigation technologies to fight heat island and improve comfort in urban environments. Sol. Energy 2014, 103, 682-703. [CrossRef]

33. Kyriakodis, G.; Santamouris, M. Using reflective pavements to mitigate urban heat island in warm climates-Results from a large scale urban mitigation project. Urban Clim. 2018, 24, 326-339. [CrossRef]

34. Radhi, H.; Sharples, S.; Taleb, H.; Fahmy, M. Will cool roofs improve the thermal performance of our built environment? A study assessing roof systems in Bahrain. Energy Build. 2017, 135, 324-337. [CrossRef]

35. Ali-Toudert, F.; Mayer, H. Numerical study on the effects of aspect ratio and orientation of an urban street canyon on outdoor thermal comfort in hot and dry climate. Build. Environ. 2006, 41, 94-108. [CrossRef]

36. Skelhorn, C.; Lindley, S.; Levermore, G. The impact of vegetation types on air and surface temperatures in a temperate city: A fine scale assessment in Manchester, UK. Landsc. Urban Plan. 2014, 121, 129-140. [CrossRef]

37. Kabisch, N.; Frantzeskaki, N.; Pauleit, S.; Naumann, S.; Davis, M.; Artmann, M.; Haase, D.; Knapp, S.; Korn, H.; Stadler, J.; et al. Nature-based solutions to climate change mitigation and adaptation in urban areas: Perspectives on indicators, knowledge gaps, barriers, and opportunities for action. Ecol. Soc. 2016, 21, 634-648. [CrossRef]

38. Scott, M.; Lennon, M. Nature-based solutions for the contemporary city. Plan. Theory Pract. 2016, 17, 267-300. [CrossRef]

39. International Union for the Conservation of Nature (IUCN). Nature-Based Solutions to Address Global Societal Challenges. Cohen-Shacham, E., Walters, G., Janzen, C., Maginnis, S., Eds.; Available online: https://portals.iucn.org/library/sites/library/files/documents/2016-036.pdf (accessed on 7 October 2018).

40. International Union for the Conservation of Nature (IUCN). Nature-Based Solutions. Available online: https://www.iucn.org/commissions/commission-ecosystem-management/our-work/nature-basedsolutions (accessed on 7 October 2018).

41. World Maps of Koeppen-Gieger Climate Classification. Available online: http://koeppen-geiger.vu-wien.ac.at/ (accessed on 7 October 2018).

42. National Weather Service Climatological Report. Available online: https://forecast.weather.gov/product.php? site $=$ NWS\&issuedby $=$ PDX\&product $=$ CLA\&format $=C I \&$ version $=1 \&$ glossary $=0$ (accessed on 7 October 2018).

43. Charles, S.L. A typology of mansionization in the inner-ring suburbs of Chicago, Illinois, 2000-2015. Housing Policy Debate 2018, 28, 832-853. [CrossRef]

44. Fraley, C.; Raftery, A.E. Model-based methods of classification: using the mclust software in chemometrics. J. Stat. Softw. 2007, 18, 1-13. [CrossRef]

45. Schwarz, G. Estimating the dimension of a model. Ann. Stat. 1978, 6, 461-464. Available online: https://www.jstor.org/stable/2958889 (accessed on 22 October 2018). [CrossRef]

46. Connors, J.P.; Galletti, C.S.; Chow, W.T. Landscape configuration and urban heat island effects: Assessing the relationship between landscape characteristics and land surface temperature in Phoenix, Arizona. Landsc. Ecol. 2013, 28, 271-283. [CrossRef]

47. How Big Is a City Block? Available online: http://www.land4ever.com/block.htm (accessed on 22 October 2018).

48. City of Portland Bureau of Planning and Sustainability. Better Housing by Design. Available online: https://www.portlandoregon.gov/bps/71903 (accessed on 10 October 2018).

49. Bruse, M. Die Auswirkungen kleinskaliger Umweltgestaltung auf das Mikroklima. Entwicklung des prognostischen numerischen Modells ENVI-met zur Simulation der Wind-, Temperatur- und Feuchteverteilung. Städtischen Strukturen. Univ. Bochum 1999. [CrossRef]

50. Höppe, P. The physiological equivalent temperature-A universal index for the biometeorological assessment of the thermal environment. Int. J. Biometeorol. 1999, 43, 71-75. [CrossRef] 
51. Gagge, A.P. An effective temperature scale based on a simple model of human physiological regulatory response. Ashrae Trans. 1971, 77, 247-262. Available online: http://hdl.handle.net/2115/37901 (accessed on 22 October 2018).

52. Weather Underground WunderMap, Portland, OR. Available online: https://www.wunderground.com/ wundermap?lat $=45.50999832 \&$ lon $=-122.69000244$ (accessed on 25 April 2017).

53. Zhao, J.; Wang, J.; Xing, Z.; Luan, X.; Jiang, Y. Weather and cycling: Mining big data to have an in-depth understanding of the association of weather variability with cycling on an off-road trail and an on-road bike lane. Transp. Res. Part A Policy Pract. 2018, 111, 119-135. [CrossRef]

54. Burchfield, R.A.; Fitzhugh, E.C.; Bassett, D.R. The association of trail use with weather-related factors on an urban greenway. J. Phys. Act. Health 2012, 9, 188-197. [CrossRef] [PubMed]

55. Gebhart, K.; Noland, R.B. The impact of weather conditions on bikeshare trips in Washington, DC. Transportation 2014, 41, 1205-1225. [CrossRef]

56. Singhal, A.; Kamga, C.; Yazici, A. Impact of weather on urban transit ridership. Transp. Res. Part A Policy Pract. 2014, 69, 379-391. [CrossRef]

57. Ninan, K.N.; Inoue, M. Building a Climate Resilient Economy and Society: Challenges and Opportunities; Edward Elgar: Cheltenham, UK, 2017; ISBN 978-1-78536-844-8.

58. Kong, F.; Sun, C.; Liu, F.; Yin, H.; Jiang, F.; Pu, Y.; Cavan, G.; Skelhorn, C.; Middel, A.; Dronova, I. Energy saving potential of fragmented green spaces due to their temperature regulating ecosystem services in the summer. Appl. Energy 2016, 183, 1428-1440. [CrossRef]

59. Lee, H.; Mayer, H.; Chen, L. Contribution of trees and grasslands to the mitigation of human heat stress in a residential district of Freiburg, Southwest Germany. Landsc. Urban Plan. 2016, 148, 37-50. [CrossRef]

60. Taleghani, M.; Sailor, D.; Ban-Weiss, G.A. Micrometeorological simulations to predict the impacts of heat mitigation strategies on pedestrian thermal comfort in a Los Angeles neighborhood. Environ. Res. Lett. 2016, 11, 024003. [CrossRef]

61. Morakinyo, T.E.; Dahanayake, K.K.; Ng, E.; Chow, C.L. Temperature and cooling demand reduction by green-roof types in different climates and urban densities: A co-simulation parametric study. Energy Build. 2017, 145, 226-237. [CrossRef]

62. Taleghani, M.; Sailor, D.J.; Tenpierik, M.; van den Dobbelsteen, A. Thermal assessment of heat mitigation strategies: The case of Portland State University, Oregon, USA. Build. Environ. 2014, 73, 138-150. [CrossRef]

63. Al-hafiz, B.; Musy, M.; Hasan, T. A study on the impact of changes in the materials reflection coefficient for achieving sustainable urban design. Procedia Environ. Sci. 2017, 38, 562-570. [CrossRef]

64. US Environmental Protection Agency. Reducing Urban Heat Islands: Compendium of Strategies, Chapters 4-5. Available online: https://www.epa.gov/heat-islands/heat-island-compendium (accessed on 23 October 2018).

65. Berardi, U.; GhaffarianHoseini, A.; GhaffarianHoseini, A. State-of-the-art analysis of the environmental benefits of green roofs. Appl. Energy 2014, 115, 411-428. [CrossRef]

66. Liu, Y.; Peng, J.; Wang, Y. Application of partial least squares regression in detecting the important landscape indicators determining urban land surface temperature variation. Landsc. Ecol. 2018, 33, 1133-1145. [CrossRef]

67. Huang, M.; Cui, P.; He, X. Study of the cooling effects of urban green space in Harbin in terms of reducing the heat island effect. Sustainability 2018, 10, 1101. [CrossRef]

68. Zhang, Y.; Murray, A.T.; Turner, B.L. Optimizing green space locations to reduce daytime and nighttime urban heat island effects in Phoenix, Arizona. Landsc. Urban Plan. 2017, 165, 162-171. [CrossRef]

69. Xu, X.; Cai, H.; Qiao, Z.; Wang, L.; Jin, C.; Ge, Y.; Wang, L.; Xu, F. Impacts of park landscape structure on thermal environment using QuickBird and Landsat images. Chin. Geogr. Sci. 2017, 27, 818-826. [CrossRef]

70. Jun, M.J.; Kim, J.I.; Kim, H.J.; Yeo, C.H.; Hyun, J.Y. Effects of two urban development strategies on changes in the land surface temperature: Infill versus suburban new town development. J. Urban Plan. Dev. 2017, 143, 04017010. [CrossRef]

71. Zhang, Y.; Zhan, Y.; Yu, T.; Ren, X. Urban green effects on land surface temperature caused by surface characteristics: A case study of summer Beijing metropolitan region. Infrared Phys. Technol. 2017, 86, 35-43. [CrossRef]

72. Peng, L.; Jim, C. Green-roof effects on neighborhood microclimate and human thermal sensation. Energies 2013, 6, 598-618. [CrossRef] 
73. Naeem, S.; Cao, C.; Qazi, W.A.; Zamani, M.; Wei, C.; Acharya, B.K.; Rehman, A.U. Studying the association between green space characteristics and land surface temperature for sustainable urban environments: An analysis of Beijing and Islamabad. ISPRS Int. J. Geo-Inf. 2018, 7, 38. [CrossRef]

74. Peng, J.; Xie, P.; Liu, Y.; Ma, J. Urban thermal environment dynamics and associated landscape pattern factors: A case study in the Beijing metropolitan region. Remote Sens. Environ. 2016, 173, 145-155. [CrossRef]

75. Liu, W.; Feddema, J.; Hu, L.; Zung, A.; Brunsell, N. Seasonal and diurnal characteristics of land surface temperature and major explanatory factors in Harris County, Texas. Sustainability 2017, 9, 2324. [CrossRef]

76. Kuang, W.; Liu, Y.; Dou, Y.; Chi, W.; Chen, G.; Gao, C.; Yang, T.; Liu, J.; Zhang, R. What are hot and what are not in an urban landscape: Quantifying and explaining the land surface temperature pattern in Beijing, China. Landsc. Ecol. 2015, 30, 357-373. [CrossRef]

77. Voelkel, J.; Hellman, D.; Sakuma, R.; Shandas, V. Assessing vulnerability to urban heat: A study of disproportionate heat exposure and access to refuge by socio-demographic status in Portland, Oregon. Int. J. Environ. Res. Public Health 2018, 15, 640. [CrossRef]

78. Tzoulas, K.; Korpela, K.; Venn, S.; Vesa, Y.; Kaźmierczak, A.; Niemela, J.; James, P. Promoting ecosystem and human health in urban areas using green infrastructure: A literature review. Landsc. Urban Plan. 2007, 81, 167-178. [CrossRef]

79. Dunn, A.D. Siting green infrastructure: Legal and policy solutions to alleviate urban poverty and promote healthy communities. BC Envtl. Aff. L. Rev. 2010, 37, 41-66. Available online: https://lawdigitalcommons.bc. edu/ealr/vol37/iss1/3 (accessed on 7 October 2018).

(C) 2019 by the authors. Licensee MDPI, Basel, Switzerland. This article is an open access article distributed under the terms and conditions of the Creative Commons Attribution (CC BY) license (http://creativecommons.org/licenses/by/4.0/). 